\title{
INJUSTICE COUNTINUITY : GENDER INEQUALITY IN JAPAN IN THE 21st CENTURY
}

\author{
Mukhlis Arifin \\ University of Indonesia, mukblis.arifin91@ui.ac.id
}

\section{๑๐}

(C)2021 by the authors. Submitted for possible open access publication under the terms and conditions of the Creative Commons Attribution-ShareAlike 4.0 International License (CC-BY-SA) license (https://creativecommons.org/licenses/by-sa/4.0/) d. DOI: http://dx.doi.org/10.30983/ bumanisme.v5i1

\begin{tabular}{l|l|l} 
Submission: May, 25-2021 & Revised:June, 25-2021 & Published: June 30, 2021
\end{tabular}

\begin{abstract}
The issue of gender equality is still a problem attached to the Japanese economic, social, political, and cultural system. The movement for Japanese liberation efforts and strived since the middle of the twentieth century is still stagnating. This problem remains inseparable from how stakeholders maintain a conservative thought. Women in the domestic sphere and women are the person who does not have the capacities as men are still the basis for reason. This paper will review how gender inequality is still a severe issue that needs to be fought for in the twenty-first century.
\end{abstract}

Keywords: Gender Inequality, Gender, Woman, Womenomics

\begin{abstract}
Abstrak
Isu kesetaraan gender masih berupa permasalahan yang erat melekat dalam sistem ekonomi, sosial, politik dan budaya Jepang. Pergerakan upaya liberasi Jepang yang telah diperjuangkan sejak pertengahan abad kedua pulub sampai saat ini masih mengalami stagnansi. Keberlanjutan isu ini tidak terlepas dari bagaimana sebuab konstruksi berpikir konservatif tetap dipertabankan oleh pemangku kepentingan. Perempuan dengan ranah domestik dan perempuan tidak memiliki kapasitas yang mumpuni daripada laki-laki masih menjadi dasar berpikir dalam permasalahan ini. Tulisan ini akan mengulas bagaimana isu ketimpangan gender masih merupakan isu serius yang perlu diperjuangkan di abad kedua pulub satu.
\end{abstract}

Kata Kunci: Ketimpangan Gender, Gender, Perempuan, Womenomics

\section{Introduction}

Japan is one of the countries with the highest economic development index in the world. This Asian economic giant is finally experiencing fragility. Japan's main problem today is the labor force crisis due to its aging population and current economic stagnation. Apart from this, Japan is still trying to maintain its conservative values. It is to put aside the role of women in the public sphere and maintain the realm of women in the domestic sector. Until now, the issue of gender inequality is still attached to this sakura country. According to the 2020 Global Gender Gap Report, Japan is ranked 120th out of 156 countries globally when it comes to gender disparities. This figure has decreased from 2018 where Japan was in position 110 out of 149 countries. It increased compared to 2017, which was position 114 out of 146 countries. This issue talks about how women experience role discrimination in the political and economic spheres.

Talking about the issue of women's liberation from the confines of patriarchal Injustice Continuity: Gender... 
thought does experience complex dynamics. Machiko Matsui (1990) wrote about the long record of the struggle for feminist thought movements to sell their ideas in Japan. From the late 1960s to the 1970s, the campus was the center of various movements. Many academics have begun to question the impact of the 1960s "economic miracle" that the Japanese government continues to indoctrinate its people. People begin to understand various forms of oppression as pollution in social life. Japanese women in the 1960s had started a wave of activism just as women in America had in the 1960s. However, Japanese women are still marginalized from the decision-making activities of leftist groups who are driving activists. Women's reproductive function is considered as an obstacle that makes women considered to have functional limitations.

In the reality of the movement, even though women's activists have been exposed to Marxist thought that prepares tools to analyze problems of social structure, women's participation is still minimal. In addition, women did not yet have the vocabulary to articulate sexism at that time. Even though activism adheres to the left for various issues that develop in Japan, women activists still feel repressed and have to fight against sexism in movement organizations.

The women's movement was initially driven by radical women activists who felt that political activity also required women's perspectives. In the 1970s, our body jargon is ours, became the trigger for the women's movement in promoting women's liberation. However, this movement could not be more active because of the obstacles to forming a national women's organization involving women housewives and professionals like the National Organization for Women (NOW) at that time (Matsui: 1990).
In addition to organizational problems, Japan's economic conditions need to be considered to see how the transformation of thinking in Japanese society. As a consequence of the "economic miracle" in 1960, Japan became a country with an advanced capsular system. This is marked by the high mobility of urbanization and the formation of small families. This rapid economic development has become one of the driving forces for the transformation of "full housewives" which was previously a luxury enjoyed by upper social class groups into a common thing. In the early 1970s the conceptions of "husband as breadwinner" and "wife as housekeeper" became a collective understanding in society (Matsui: 1990).

In the early 1970s the condition of young women as workers, but being laid off when married was common in Japanese society. The illusion of matriarchy lulls middle-class women as the holder of the household coffers and holds full control of children's education as a comfort zone for these housewives. However, this condition did not last long since the economic conditions in the late 1970s, housewives who did not have these skills were forced to work in the formal sector to meet household responsibilities. In the 1980 s, one issue in Japan showed that the number of working housewives exceeded the number of fulltime housewives. Japanese feminists at that time pushed for a regulation on equal employment opportunities in 1985 (Matsui: 1990).

Mistu Tanaka is one of them, the driving force for the uumanlibu (women's liberation). Tanaka in the early 1970s said that being free does not mean in general you can meet the crossroads of life like men. I don't want children or boys. What I want is self-strength. Although ridiculed by male 
critics and journalists, her statement is one of the triggers for the manifesto of the contemporary Japanese feminist women's movement. The movement that Tanaka promotes is driven by the various aspects he has gone through in life. Tanaka is a figure who experienced trauma in the form of rape at the age of eight, lived in a broken family, experienced sexist treatment in the work environment, and was disappointed in the male-oriented political movement felt by women in his generation (Matsui: 1990).

This issue in the twentieth century shows how women's efforts to fight for their rights against patriarchal oppression are rooted in the fabric of Japanese society. Based on the background described, this paper will review how the condition of gender equality that became a struggle at the end of the twentieth century experienced a setback. The discussion of this paper uses an analysis of literature studies based on several writings and analysis of recent cases related to the issue of gender disparity and gender inequality in Japan.

\section{Discussion}

\section{The Struggle for Gender Equality in Japan}

According to the introduction section, the struggle of Japanese women to voice gender-based justice. Hasunuma (2015) explained, In the 1947 occupation era, women's associations were incorporated in the Women's and Minor Bureu (WMB), which only dealt with labor issues. At that time, efforts to demand equality were voiced by feminist activists through the Japanese Socialist Party, the Democratic Socialist Party, and the Communist Party. However, women continue to experience discrimination, even within the union itself. It is because the presence of women is considered temporary and only fills also tend to become mothers.

Furthermore, women are also far from union protection because their presence is considered temporary. Cook and Hayashi in Hasunuma (2015) explain that Japan's activism alliance is also less strong in establishing cooperation between women's movements, women politicians, government institutions, national bureaucrats, activists, and the Ministry of Manpower which is dominated by the interests of male workers. The various patterns of participation of women activists, academics, journalists, advocates, and the community in general hamper the continuity of relationships.

Japan's participation in the United Nations and the emergence of discussions on gender issues, the movement's efforts began to show the way. However, in field practice, the Japanese Ministry of Education, which dominates decision-making, adheres to traditional values and nationalistic ideas, these expectations still face challenges. The Japanese Ministry of Education formulated a policy that women need to be educated to become mothers. The implication of this is that mothers are the central figures for educating children, especially in rebuilding post-war conditions (Hasunuma: 2015). The position of the Ministry of Manpower which is not considered a crucial position in Japan, efforts to place gender issues and position women in the ranks of bureaucrats are again hampered.

Japan first attended the World Conference on the Status of Women in 1975, in Mexico. This conference contains an International Plan of Action to realize gender equality which includes references for state governments and the international community to follow the agreed decade plan. The plan of the meeting in 1980 expected that there would be efforts from each of the participating countries to 
implement equal opportunities for employment opportunities, political participation, opportunities for health services, physical health, housing, family planning plans and education for women.

Abe uses this framework to promote plans to empower women. The thing that pressures Abe to carry out the "womennomics" plan is international pressure or gaiatsu. International forums emphasized the discriminatory treatment of women and during the war that made women a "satisfactory" political tool for soldiers during the occupation. This makes Japan have a bad reputation in the international community's eyes regarding the issue of women's rights (Hasunuma: 2015).

\section{The Mirage of Womenomic}

Abenomics was a pillar of Shinzo Abe's policy when he was elected Prime Minister of Japan in 2012. This policy seemed to give hope to advance the increasing role of women in the workplace to create a society with the jargon "all women can shine". By explicitly linking Japan's economic revitalization strategy and increasing the number of women workers, this is strung together into one of its programs with the title "womenomics" as part of formal and informal policy tools. In particular, the Abe government proposes that the empowerment of women in the Japanese economic sector, represented by women's employment in the labor market, is one of the main policy priorities for the revitalization strategy of Japan's sluggish economy.

Interestingly, during Abe's tenure as prime minister, he built a reputation as someone who upholds traditional ideas and values about the Japanese family. Why would a conservative prime minister - and coming from a political party with a history of preserving women's roles as mothers and housewives - championing the role of women in the workforce and encouraging other activities outside the home? Womenomics had two important goals: (1) its focus on the female workforce could help Japan manage pressing demographic, labor, and economic pressures; and (2) giving Abe the power to redefine Japan's role, ranking and reputation in the international community on matters relating to Japan's economic performance and his record on women's issues - two areas that international investors and activists are regularly monitoring. Womenomics may have started as a strategy to add to demographic pressures and labor shortages, but it has also become an essential public advocate.

The Japanese government has discussed increasing the number of employment opportunities for women over the last few decades, but the Abe government's women's employment policies are formulaically different from previous policies. First, the Abe government began to highlight efforts to increase competitiveness and profitability for companies as one of the important advantages in the workplace (for example, recruitment of women workers and promotion of women to leadership positions). Instead of emphasizing increasing gender equality as a social norm, this policy seems to prioritize women's economic strengthening in optimizing Japan's economic revitalization strategy and business management strategy. The graph below shows how the ratio of the number of women involved in the government sector and how women's participation in the managerial field is at an unbalanced number (Song: 2015). 


\section{Graphic 1.1}

The proportion of women and women's participation in the managerial realm in government agencies in 2012.

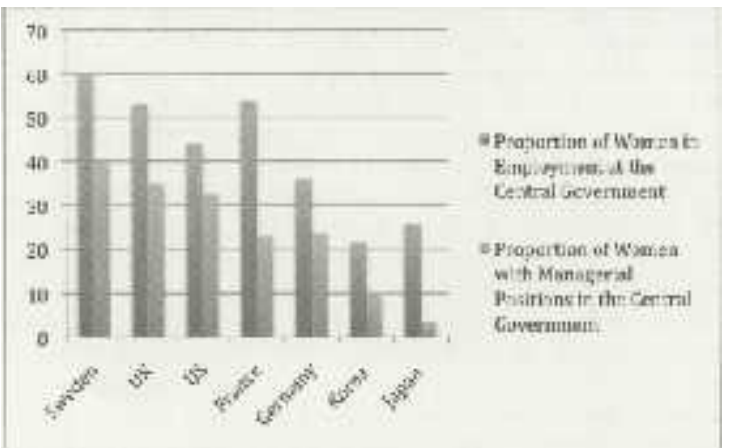

Source: Jiyeon Song, Evolution of the Feminist Movement in Japan: 2015

The Abe government's policy targets for women's work can be summarized as follows: (1) increased female labor force participation and (2) promotion of women in leadership positions (e.g., managers and executives). It needs to be reflected in a survey conducted by the government that about $40 \%$ of women decide to leave the work environment after giving birth to their first child due to their "dedication" to taking care of children and doing work at home, and $30 \%$ of women feel unable to meet the balance of life between work and daily life. For this, the Abe government plans to build 400,000 child care centers with a target to be achieved by 2017 .

Since 2013, the Abe government has proposed a series of policy initiatives to increase women's employment, provide support for women in balancing the work and lives of women workers, and create a women-friendly and family-friendly social and work environment. This policy includes respecting and recognizing the achievements of women in corporations and providing promotions for women who are active in corporations.

The "womenomics" campaign tries to refute the title given to Japan that Japan has low respect for women and does not pay attention to women's rights. It shows how important it is conceptually for womenomics in an effort to increase the rank of women's participation in the economic and political sphere, which has consistently fallen at the bottom. Coleman (2016) argues that, fundamentally, all women worldwide can agree that what is needed is not just an increase in the quantity of women's participation. Both women and men need an open discussion space to form a collective agreement in social life.

Kingston (2013) sharply criticized Abe's Womenomic. Kingston's argument says that Abe is aware that women are a marginalized group in the top ranks of the corporate sector in Japan, but this is only limited to realizing and taking no action to change the situation. Abe promised to provide enough daycare for mothers, but the salaries earned by mothers who work fulltime are $27 \%$ less than men who work at the same level. In the ranks of corporate directors, women only fill $2 \%$ of the seats and $11 \%$ at the managerial level while $74 \%$ of women with academic qualifications resign from their jobs voluntarily due to the pressure they face. This shows how low career expectations are for women.

Fundamentally, this is a threat to womenomics which is predicted to move Japanese women. In addition, Abe also did not encourage the welfare of the Japanese precariate class who was trapped in a lowwage bond without insurance and health insurance. At least in 2013 there were 20 million workers who were in unfavorable conditions. This is sufficient to explain that the number of children raised under poverty pressure in Japan reached 14.3\% (Kingston: 2013).

\section{Current Problems in the 21st Century}

\section{University of Tokyo Medical School Gender Discrimination}


On August 2, 2018, an article published by the Yomiuri newspaper broke the reader's attention. Rumors spread that the University of Tokyo Medical School systemically lowered female examinees' grades to benefit male examinees. This news spread after an investigation was held involving the son of a high-ranking official from the Japanese Ministry of Education, Sano Futoshi who took the entrance exam for the University of Tokyo Medical School. The examination committee deliberately controlled the grades of Sano's children with the lure of guaranteeing to improve the public image of the campus. Along with the depth of the investigation, it was later revealed that the campus systematically cheated by outsmarting the test takers' scores. In this context male examinees tend to benefit. This is based on the argument that women will not be able to show good performance in the medical field, so this doctrine has continued for more or less the last decade (Schieder: 2019).

Ironically, in 2013, the campus received grants for a "support women" program. For more than three years, the University of Tokyo Medical School received 80 million yen (approximately 10.5 billion rupiah) from the program. Two executives from the University of Tokyo Medical School, Usui Masahiko and Suzuki Mamoru played an important role in promoting the "diversity" that was developed within the campus academic community which began in 2016. During the opening ceremony for the anniversary of the "diversity" program in 2017, Usui proclaiming how the efforts of the University of Tokyo Medical School were able to increase the number of female students from $26.9 \%$ to $32.4 \%$ as a form of collective hard work (while covering up the systematic manipulation of numbers from female examinees whose scores were reduced in a structured manner by the system). This shows that not only the campus has suppressed the number of women's participation, but has also cut the aid funds that should be received by female students. In addition, this problem is exacerbated by cheating on the part of the test organizers who tapped the registration fee of female examinees "who will be systemically thwarted" of 40,000 to 60,000 yen (about 5 million to 8 million rupiah).

The male organizers who implemented gender-based discrimination at the Tokyo Medical School framed their action as a "major crime." The main reason for this activity is that too many female doctors leave their jobs to give birth to children or get married. In addition, another supporting reason is that "as women get older, the level of activity in the medical field will decrease." This doctrine seems to legitimize that women are physically incapable and their capacity to become a doctor (Schieder: 2019).

\section{Gender-Based Discrimination in Japan's Olympic and Paralympic Administration}

In 2013, Japan won the battle for the chance to host the Olympics and Paralympics. This competition will be held in Tokyo in 2020. With the Covid-19 pandemic, this activity had to be shifted to be held in 2021. With preparations getting closer and pressure to suppress the pace of the pandemic in Japan, a news broke that caused a stir in preparation for the sports event. the international. Reported from The Diplomat on February 12, 2021:

"Mori Yoshiro resigned Friday as the president of the Tokyo Olympic organizing committee following sexist comments implying that women talk too much. 
"As of today I will resign from the president's position," he said to open an executive board and council meeting. The board was expected to pick his successor later on Friday.

Mori's departure comes after more than a week of non-stop criticism about his remarks earlier this month. He initially apologized but refused to step away, which was followed by relentless pressure from television pundits, sponsors, and an online petition that drew 150,000 signatures.

But it's not clear that his resignation will clear the air and return the focus to exactly how Tokyo can hold the Olympics in just over five months in the midst of a pandemic.

The Olympics are set to open on July 23, with 11,000 athletes and 4,400 more in the Paralympics a month later. About 80 percent in recent polls in Japan say they want the Olympics canceled or postponed with clear support at about 15 percent.

Early reports said the 83-year-old Mori had picked 84-year-old Kawabuchi Saburo, the former president of the governing body of Japanese soccer and a former player himself. He played for Japan in the 1964 Olympics.

Kawabuchi is even older than Mori and will raise the issue of why a woman was not appointed. This is the center of the entire debate that Mori triggered over gender inequality in Japan and the absence of women in boardrooms, politics, and sports governance. Women are also largely absent in leadership roles at the organizing committee.

Kawabuchi indicated on Thursday he had been contacted by Mori. But he later indicated he might not be the appropriate choice.

Japanese media immediately pointed out there were three qualified women - all athletes and former Olympians and at least a generation younger - who could fill the job.
Yamaguchi Kaori won a bronze medal in the 1988 Olympics in judo. Kotani Mikako won two bronze medals in the 1988 Olympics in synchronized swimming. And Takahashi Naoko was a gold medalist in the marathon in the 2000 Olympics.

Hashimoto Seiko, the current Olympic minister and a former Olympian, has also been mentioned as a candidate.

Mori's remarks have put the spotlight on how far Japan lags behind other prosperous countries in advancing women in politics or the boardrooms. Japan stands 121st out of 153 in the World Economic Forum's gender equality rankings.

Nakano Koichi, a political scientist at Sophia University in Tokyo, characterized Japan as a country still run "by a club of old men." But he said this could be a watershed moment.

"Social norms are changing," he wrote in an email to The Associated Press. "A clear majority of the Japanese found Mori's comments unacceptable, so the problem is more to do with the lack of representation of women in leadership positions. This sorry episode may have the effect of strengthening the call for greater gender equality and diversity in the halls of power."

Though some on the street called for Mori to resign - several hundred Olympic volunteers say they are withdrawing - most decision makers including Japanese Prime Minister Suga Yoshihide stopped short of this and simply condemned his remarks..."

Berita senada juga ditampilkan oleh media The New York Times, 18 Februari 2021:

"TOKYO - Bending to intense criticism from abroad and social media activism at home, the Tokyo Olympic organizing committee on Thursday appointed Seiko Hashimoto, one of Japan's two female cabinet 
ministers, to replace the previous leader, who resigned last week after making sexist remarks.

The selection of Ms. Hashimoto, 56, an Olympic medalist in speedskating, represented a stark generational and gender shift for the committee. The man she is succeeding, Yoshiro Mori, is an 83year-old former prime minister who stepped down after saying that women talked too much in meetings. The man the committee had initially planned to turn to next - Mr. Mori's handpicked choice is an 84-year-old former leader of Japanese soccer.

The appointment of Ms. Hashimoto did not stray far from the entrenched establishment that governs Japan. But both Mr. Mori's resignation and his successor's ascension reflected the potent voice that Japanese people especially women in a male-dominated society - have found online, swaying the course of what was viewed as an important symbolic decision.

"In the past, he would have been just criticized, and then the issue would have ended," said KazuyoKatsuma, a businesswoman and prominent author of best-selling books on gender and worklife balance, speaking about Mr. Mori. "But this time he had to resign because of a lot of criticism from women who raised their voices."

Yet even as some praised the capitulation of Mr. Mori, others wondered whether Ms. Hashimoto's appointment was much more than a cosmetic decision, made under duress, in a country that ranks 121st out of 153 countries in the World Economic Forum's global gender gap index. Some of the most significant criticism of Mr. Mori had come from outside Japan, with many traditionalists inside the country defending him..."
These two news stories are only representations of various media that highlight issues that are quite sensitive at this time. Gender-based discriminatory expressions on the international stage have significant differences with the local stage. Clearly, the patriarchal form of culture is still attached to Japanese government bodies, especially conservative groups. The implications of these remarks on the international stage podium certainly have strong implications for the reins of power held by Mori, who was previously president of the Olympic and Paralympic Games.

\section{Woman and Liberation}

$$
\text { Martin Taarn Pedersen }
$$

conducted a study that questioned whether there were significant changes to finances if women were on the board of directors of a company? Pedersen conducted this research to examine the plan of one of Shinzo Abe's policy arrows "womenomics" as a strategy to strengthen women's economy. Pedersen (2013) found that the rumors that have occurred so far only speak the same pattern, the presence of women only causes a decrease in the company's financial performance. According to a 2012 report by Booz \& Company, Japan would gain a 9 percent net impact on GDP simply by increasing the female labor force participation rate. What has been maintained so far is that women are not able to do various things like men. Pedersen (2013) conducted empirical research to examine the stigma of whether women are able to increase the company's financial productivity if they are at the board of directors level. The data used in Pedersen's (2013) study includes a snapshot of the gender composition of the board of directors in fiscal 2012, coinciding with the implementation of structural reforms 
proposed by the Abe Administration. Thus, Pedersen hopes that his statistical-based research can provide a healthier view.

The results of Pedersen's research (2013) show that women are able to manage their responsibilities if they are in the board of directors. The results of his research show that policy makers should not ignore arguments about initiatives to increase the share of female corporate leaders, including female board members in Japan, either in the form of targeted incentive schemes or mandatory quotas. The problem of endogeneity and inverse causality in the presented regression results does not necessarily invalidate the formulation of policies based on current firm-level financial performance data. A number of additional economic incentives are possible if the inclusion of Japanese women serving on the board of directors emerges as part of the plan, including increased market initiatives, increased auditing of corporate practices, and expansion of skills-based employment opportunities.

In general, the performance of women in top managerial positions is not only debated in Japan. Chistian L. Dezsö and David Gaddis Ross (2012) previously conducted a similar study to analyze the performance of women on the top board of directors in a company. Dezsö and Ross (2012) found that in general women can have a significant impact on improving company performance if they are given the power to manage a company.

Apart from this, the discussion on women's liberation that is currently being formed still has a long way to go in its movement. Shim (2018) underlined, although Japan has had a long history of women's struggles, Japan does not yet have a national-scale umbrella organization capable of instilling an ideology regarding women's democratic rights to left or right party groups.

\section{Conclusion}

The condition of Japan's economic stagnation and Japan's aging labor force population can logically open up potential good opportunities to reinvent people who have been marginalized (women) by the system to enter the workforce, especially as changes in political administration increasingly recognize the potential of women as catalysts. Economic development potential. This demands that the planned political policy shift no longer speaks at the level of discourse without redefining the social construction that has been built in Japan.

The fundamental problem of the stagnation of efforts to realize gender equality in Japan is not rooted in the lack of quantitative involvement of women, but the main thing is in the construction of discriminatory thinking. This condition will last and will continue to decline if the Japanese government does not seek an alternative perspective to the public and executives in companies that continue to perpetuate women's conservative thinking as guardians of the domestic domain.

\section{Bibliography}
Coleman, Liv. 2016. Will Japan "Lean In" to Gender Equality?.U.S.-Japan Women's Journal, 2016, No. 49 (2016), Hal. 3-25. University of Hawai'i Press

Dezsö, Christian L. dan David Gaddis Ross. 2012. Does Female Representation in Top Management Improve Firm Performance? A Panel Data Investigation. Strategic Management Journal, Vol. 33, No. 9, hal 10721089: Wiley 
Hasunuma, Linda C. 2015. Gender Gaiatsu: An Institutional Perspective on Womenomics. U.S.-Japan Women's Journal, 2015, No. 48 (2015), Hal. 79-114. University of Hawai'i Press

Kingston, Jeff. 2013. The Illusion That is Abenomics. Economic\&Political Weekly

Matsui, Machiko. 1990. Evolution of the Feminist Movement in Japan. The John Hopkins University Press

Pedersen, Martin Taarn. 2013. Girl Power in Japanese Boardroom? An Exploratory Study of Critical Masses Impact of Firm on Financial Performance. Journal of International Affairs Editorial Board

Schieder, Chelsea Szendi. 2019. A "Necessary Evil"? Keeping Women Out of Medical Schools Won't Fix What Ails the Japanese Medical Profession. The Asia-Pasific Journal: Japan Focus. Vol. 17, Issue 7, No. 2.

Shim, Jaemin. 2018. Mind the Gap! Comparing Gender Politics in Japan and Taiwan. German Institute of Global and Area Studies.

Song, Jiyeoun. 2015. Economic Empowerment of Women as the Third Arrow of Abenomics. Journal of International and Area Studies, June 2015, Vol. 22. No. 1 (June 2015), hal. 113128. Institute of International Affairs, Graduate School of International Studies, Seoul National University

\section{Online Reference}

https://www.japantimes.co.jp/news/2021/ 03/27/national/mori-sexistremark-women/, diaksesJumat, 21 Mei 2021

https://www.dw.com/en/japan-genderequality-sexism/a-57102279, diaksesJumat, 21 Mei 2021 https://www.nytimes.com/2021/02/18/wo rld/asia/yoshiro-mori-tokyoolympics-seiko-hashimoto.html, diaksesJumat, 21 Mei 2021

https://thediplomat.com/2021/02/tokyoolympics-mori-to-leave-butgender-issue-remains/, diaksesJumat, 21 Mei 2021 